\title{
定常および過大過小応力下の表面疲労き裂伝ぱに 及ぼす平均応力の影響
}

\author{
藤 田 和 孝* 小寺沢良 - $^{* *}$ 谷 本

\begin{abstract}
Effect of Mean Stress on Surface Fatigue Crack Propagation under Constant Amplitude Stressing and Periodic Overstressing
\end{abstract}

曻*

by

\author{
Kazutaka FujitA*, Ryoichi KoterazAwA** and Noboru TANIMOTO*
}

The effect of mean stress on growing surface fatigue cracks in bending plates of annealed $0.20 \% \mathrm{C}$ steel was studied under constant amplitude stressing and periodic overstressing. In constant amplitude stressing tests, the crack was semi-elliptic and had a smaller aspect ratio under compressive mean stress than under tensile mean stress. The crack propagation rate in depth direction was almost equal to that in surface direction for the same $\Delta K$ value when mean stress was tensile $(R=0)$. When mean stress was compressive $(R=-2)$, the former was lower than the latter. In periodic overstressing tests, the crack propagation rate became remarkably accelerated (several hundred times) as mean stress changing from tension to compression. Large acceleration (more than one hundred times) also occurred even in the case of tensile mean stress of overstress provided that it was large enough $(R=0)$. The fracture surface morphology in most cases except small acceleration showed that the crack propagated in zigzag manner in the same way as the cases with large acceleration in through-thickness cracks reported previously.

Key words : Fatigue, Crack propagation, Fractography, Fracture mechanics, Variable stress, Mean stress, Surface crack, Acceleration of crack propagation

\section{1 緒言}

実機で見られる疲労破壊の多くは，表面欠陥や応力 集中部等を起点として発生した表面き裂の伝ぱによる. このため表面き裂の伝ぱについては従来から多くの研 究が行われて来ている. しかし, 平均応力が圧縮の場 合も含み表面および内部の伝ぱを詳細に調べた例は少 ないようである。また実機に加わる変動荷重を模擬し た過大過小応力下のき裂伝ぱについて, 巨視貫通き 裂や微視き裂と同様, 表面き裂においても顕著な加速 が筆者の一人らにより観察されているが, 平均応力が 加速挙動におよぼす影響はまだ調べられていない.そ こで本研究においては種々の平均応力を用いて, 定常 および過大過小応力下の表面疲労き裂伝ぱ試験を実施 し, 平均応力がき裂伝ぱ挙動に及ぼす影響について検 討した。

\section{2 試 験 方 法}

供試材は S20C焼ならし材（機械的性質: 降伏応力 $271 \mathrm{MPa}$, 引張強さ $456 \mathrm{MPa}$ ，伸び $30.8 \%$ ）である. 試験片は平行部板幅 $25 \mathrm{~mm}$ 板厚 $4 \mathrm{~mm}$ であり, 表面 中央に直径 $0.3 \mathrm{~mm}$ 深さ $0.2 \mathrm{~mm}$ のドリル穴を加工し,
き裂発生箇所とした。試験には，シェンク式平面曲げ 疲労試験機 $(40 \mathrm{Nm}, 3600 \mathrm{cpm})$ を用いた。応力拡 大係数 $K$ の算出には Newman-Raju の式を用いた. 定常応力下のき裂伝ぱ挙動は応力比 $R$ を $0,-1,-2$ (それぞれ片振り，両振り，圧縮の平均応力を有する 両振り）とし荷重一定試験により，また $\Delta K_{\mathrm{th}}$ は荷重 漸減試験（ASTM の方法に準じ荷重減少率 1 割以内, 片側き裂伝ぱ増分約 $0.5 \mathrm{~mm}$ ）により求めた．過大過 小応力下のき裂伝ぱ挙動は, $\Delta K_{\mathrm{th}}$ 以下の過小応力拡 大係数幅 $\Delta K_{1}$ を $2.2 \times 10^{5}$ 回負荷後, 過大応力拡大係 数幅 $\Delta K_{2}$ を手動（約 $0.5 \mathrm{~Hz}$ ）により 2 回負荷して 1 ブロックとし，これを繰返す二段多重試験により求め た. 試験には， $\Delta K_{1}$ と $\Delta K_{2}$ の平均応力（それぞれ $\left.K_{1 \mathrm{~m}}, K_{2 \mathrm{~m}}\right)$ はおのおの一定とし, 両者を等しくおい た Table I に示す負荷プログラム I， II， III（それぞ れ平均応力が圧縮, ゼロ, 引張り), および過小応力 はすべて片振りで $K_{2 \mathrm{~m}}$ を变えた同 V, III， IV（それ ぞれ $K_{2 \mathrm{~m}}$ が圧縮, 引張り, 片振りのさらに大きな引 張り）を用いた. 各負荷プログラムとも $\Delta K_{1}$ は 0.9 $\times \Delta K_{\mathrm{th}}, \Delta K_{2}$ は表面方向のき裂伝ぱ速度が $1 \times 10^{-5}$

$\dagger$ 原稿受理 平成 2 年 8 月21日 Received Aug. 21, 1990

* 正 会員 宇部工業高等専門学校 宇部市常盤台, Ube Technical College, Tokiwadai, Ube

** 正会員 筑波大学構造工学系 つくば市天王台, Institute of Engineering Mechanics, University of Tsukuba, Tennoudai, Tsukuba 
$\mathrm{mm} / \mathrm{c}$ となる值とした．な扮負荷プログラム I， III の $\Delta K_{2}$ の応力比 $\left(R_{2}=-1.35,-0.5\right)$ におけるき裂 伝ぱ速度と $\Delta K$ の関係は，定常応力下のき裂伝ぱ試 験結果（ $R=0,-1,-2)$ を用いて内挿により推定 した。き裂長さの測定は，表面方向はき裂伝ぱ量の多 い荷重一定試験では読取り顕微鏡（100 倍，分解能約 $10 \mu \mathrm{m})$, き裂伝ぱ量の少ない荷重溸減試験や 2 段多 重試験ではレプリカを採取し，それを金属顕微鏡 (500 倍，分解能約 $1 \mu \mathrm{m}$ )により行った。また深さ方 向は破面を実体顕微鏡を用いて撮影し，写真（総合倍 率約 40 倍）上でビーチマーグを基に行った。き裂開 閉口挙動の測定はひずみゲージを用いたコンプライア ンス法により行った。き裂最深点付近の開閉口は試験 片背面中央に, 表面付近のそれは表面のき裂先端前方 にそれぞれ貼付したゲージ出力から求めた。

\section{3 試験結果と検討}

\section{$3 \cdot 1$ 定常応力下のき裂伝ぱ}

実体顕微鏡によるマク口破面写真例を Fig. 1 に，こ のような破面写真上で求めたき裂前縁のアスペクト比 $a / b$ と表面方向のき裂長さ $2 b$ の関倸を Fig. 2 に示す. 同図の实線はそれぞれ $R=0,-1,-2$ のデー夕の平 均值である。デー夕にバラッキは見られるものの, $a / b$ は $R$ が $0,-1,-2$ と平均応力が引張りからゼ 口，圧縮となるにつれ小さくなっている，マクロ破面 写真例（Fig. 1）を少し注意して見ると， $R=0$ では 内部が表面付近と比べ少し黒ずんで㧍り，R=-1で も同様であるがその差は $R=0$ よりも幾分大きく，ま

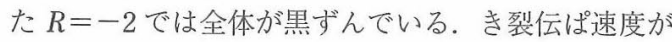
ほぼ等しい（約 $2 \times 10^{-6} \mathrm{~mm} / \mathrm{c}$ ) 領域の SEM による ミクロ破面写真例を Fig. 3 に示す。 $R=0$ と -2 打よ びそれぞれの表面と内部の破面様相は，いずれもこの
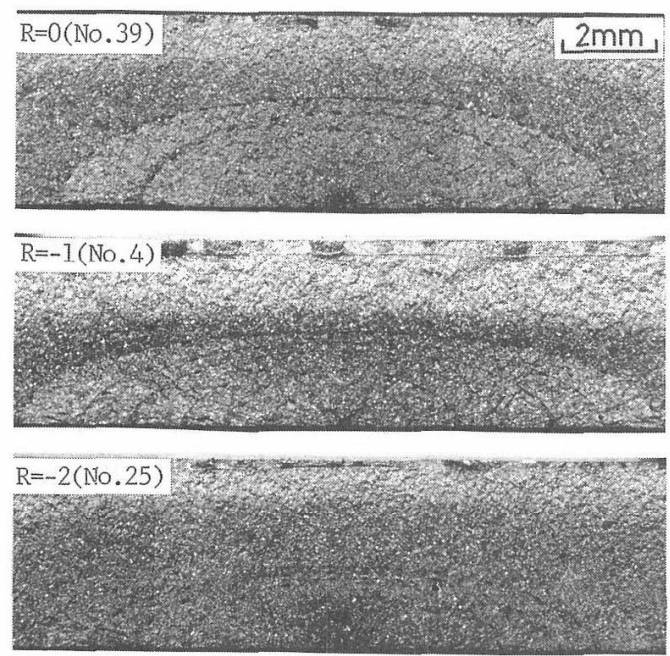

Fig. 1. Macrofractographs of specimens tested under constant amplitude stressing.

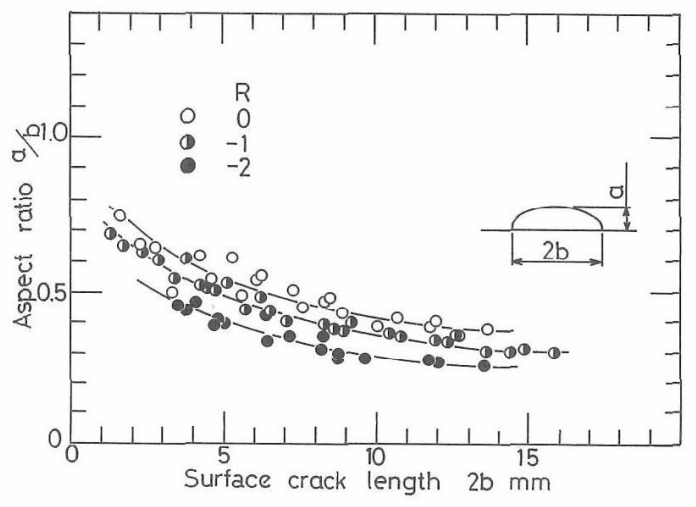

Fig. 2. Aspect ratio of surface cracks under constant amplitude stressing.

ような低伝ぱ速度域の特徽であるき裂伝ぱ方向に平行 な幅の狭い多数のプラトーとプラトー上のストライエ ーション状模様からなり，微視的破壊機構に明りょう な差異は見られなかった， $R$ が 0 から $-1,-2$ 亿, すなわち平均応力が引張りからゼロ，圧縮に変わると $a / b$ は小さくなったが, これは, 平均応力が引張り よりもゼロの場合の方が表面に対する内部の黑ずみ具 合いが大きく，また破面全体の黑ずみ具合いは平均応 力が引張りからゼロ，圧縮となるにつれて大きいとい うマクロ破面写真の観察結果から, 酸化物誘起き裂閉 口が関係しているのではないかと思われる。

表面方向㧍よび深さ方向のき裂伝ぱ速度（それぞれ $d b / d n, d a / d n)$ と $\Delta K$ の関係を Fig. $4(a)$ に示す. 図中白抜き印は $R=0$, 半黒叙印は -1 , 黒塗印は -2 を, また横棒なしの印は $d b / d n$, 横棒付きの印 は $d a / d n$ を示す。従来から報告されているように $R$ 依存性が見られ， $R$ が $0,-1,-2$ の順にき裂伝ぱ 速度は小さくなっている. $d b / d n$ と $d a / d n$ を比べ ると，後者のデー夕点は少数でかつ低速度域に限られ ているが， $R=0$ の引張りの平均応力下では両者はほ ほ等しく $,-1,-2$ とゼロから圧縮の平均応力にな るとともに $d b / d n$ に比べ $d a / d n$ が小さくなって拧 り，アスペクト比で見られた結果と対応している.

コンプライアンス法によりき裂開口比 $U$ (き裂先 端開口応力範囲 / 全応力範囲) を求め, これを用いて 得た $\Delta K_{\text {eff }}(=U \times \Delta K)$ によってき裂伝ぱ速度を再整 理した結果を Fig. 4 (b)に示す, 全速度範囲に扔いて 明りょうな $R$ 依存性は見られず，低伝ぱ速度域では 実験点の带域が下方に折れ曲がり, $\left(\Delta K_{\mathrm{eff}}\right)_{\mathrm{th}}$ 方存在し

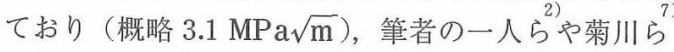
の報告と同傾向を示している．また $\Delta K$ 線図におい

*1 荷重一定試験では平均応力は変えず応力振幅を下げて入れ，二段 多重試験では試験開始時は試験条件が予き裂条件 (表面方向のき 裂伝ぱ速度が約 $1 \times 10^{-6} \mathrm{~mm} / \mathrm{c}$ ) と異なるため入り, 試験終了時 は液体窒素を用いて低温ぜい性破断芑せ入れている. 


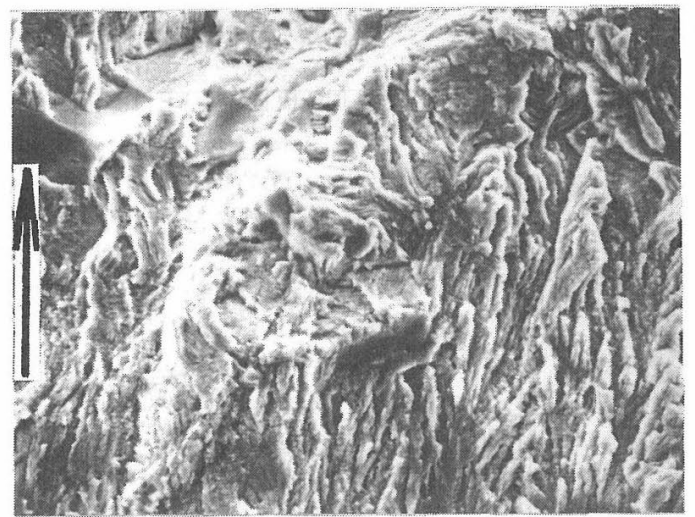

near deepest region

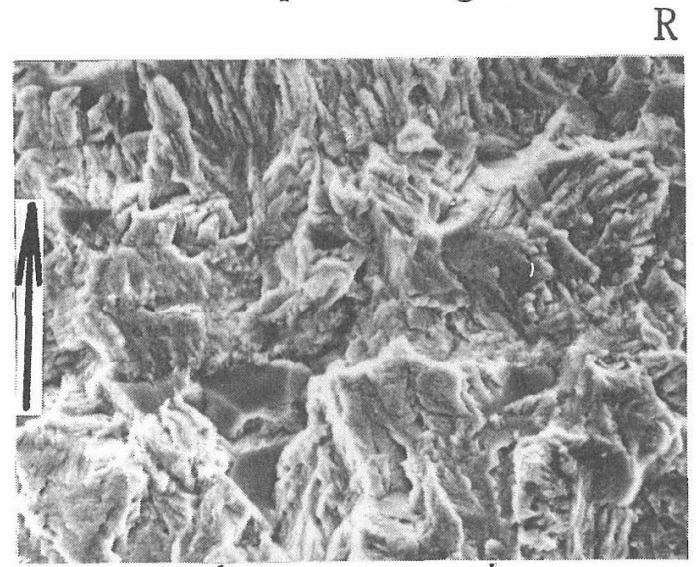

near deepest region

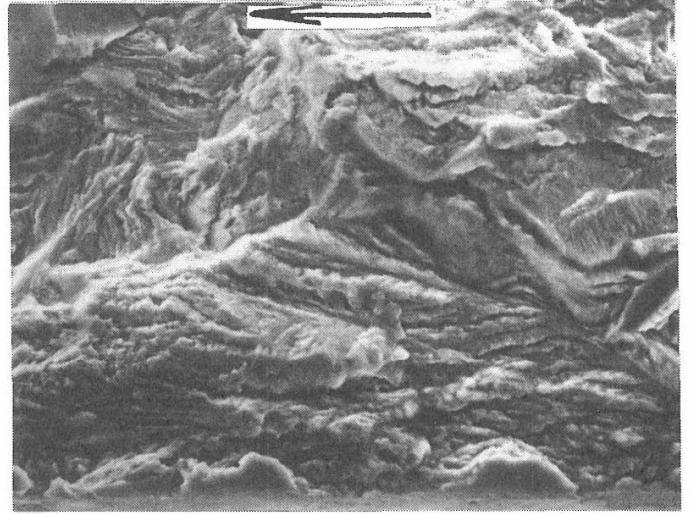

near surface region

$\mathrm{R}=0$

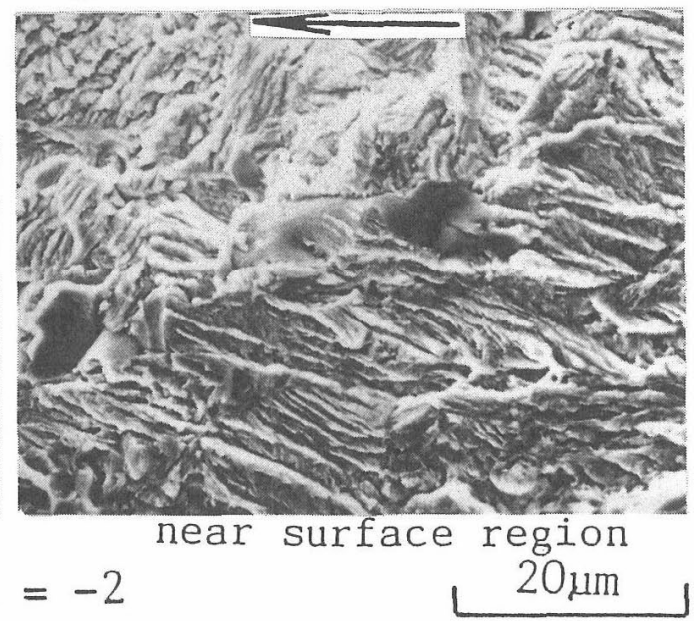

Fig. 3. Microfractographs of speimens tested under constant amplitude stressing.

て $R=-1,-2$ と平均応力がビロから圧縮になると ともに $d b / d n$ に比へ $d a / d n$ が小さくなったが, $R=-2$ においても，試験片表面のき裂先端前方ゲー ジ出力から得た $U$ 值と, 背面中央のゲージ出力から 得た $U$ 值に差異は見られず $(R=0,-1$ においても 同様), $\Delta K_{\mathrm{eff}}$ 線図においても $d b / d n$ と $d a / d n$ 間の 差異は残っている (ムとニ印や○と○印). 前述 のようにマクロ破面観祭結果は，この差異がき裂閉口 現象の違いにより生じた可能性を示唆しており，また 本コンプライアンス法では背面ゲージの出力はき裂の 最深点も含めた前縁のかなり大きな範囲の平均的な $U$ 值を示し, そのため表面と背面のゲージ出力から 得たU 值間に差異が見られなかったことも考えられ る. 今後局所的な $U$ 值の測定が可能な超音波法を用 いた検討を行う予定である。

\section{$3 \cdot 2$ 過大過小応力下のき裂伝ぱ}

過大過小応力下のき裂伝ぱ試験結果をTable I に示 す. 同表中の $R_{\mathrm{ac}}$ は加速率を, $\overline{R_{\mathrm{ac}}}$ は各負荷プログラ ムごとの $R_{\mathrm{ac}}$ の平均值を示している. 種々の平均応
力を用いた本表面き裂伝ぱ試験においても，従来から 報告している巨視貫通き裂拉よび表面き裂や微視き裂 と同様, 条件によっては数百倍という極めて高い加速 を生じている.

Table I において, 過大, 過小の各平均応力 $K_{2 \mathrm{~m}}$, $K_{1 \mathrm{~m}}$ を等しくおき，それを変えた負荷プログラム I， II， IIIを見ると，平均応力が引張り（III）, ゼロ（II）, 圧縮（I）の順に表面 ( 0 。方向)および内部 $\left(60^{\circ}\right.$ 方 向）とも加速率 $R_{\mathrm{ac}}, \overline{R_{\mathrm{ac}}}$ は大きくなっている.また 表面と内部を比べると I, I の場合表面の加速の方が 大きく，加速があまり大きくないIIIの場合にはほほ等 しい.ここで内部は $60^{\circ}$ 方向で評価したが，これはき 裂伝ぱ量の少ない場合に $90^{\circ}$ 方向では伝ぱ量を測定で きなかったためである。平均応力が引張り, ゼロ，圧 縮の順に加速が大きくなるのは, 圧縮応力負荷による 圧縮残留応力の解放が影響しているものと考えられる.

*2 過大過小応力試験中の実際のき裂伝ぱ量を, 過大過小の各応力段 階ではそれらを定常的に負荷した場合の伝ぱ速度に等しいとして 求めた伝ぱ量で除した值であり, 疲学寿命を評価する際に用いら れるマイナー則の逆数に相当する. 


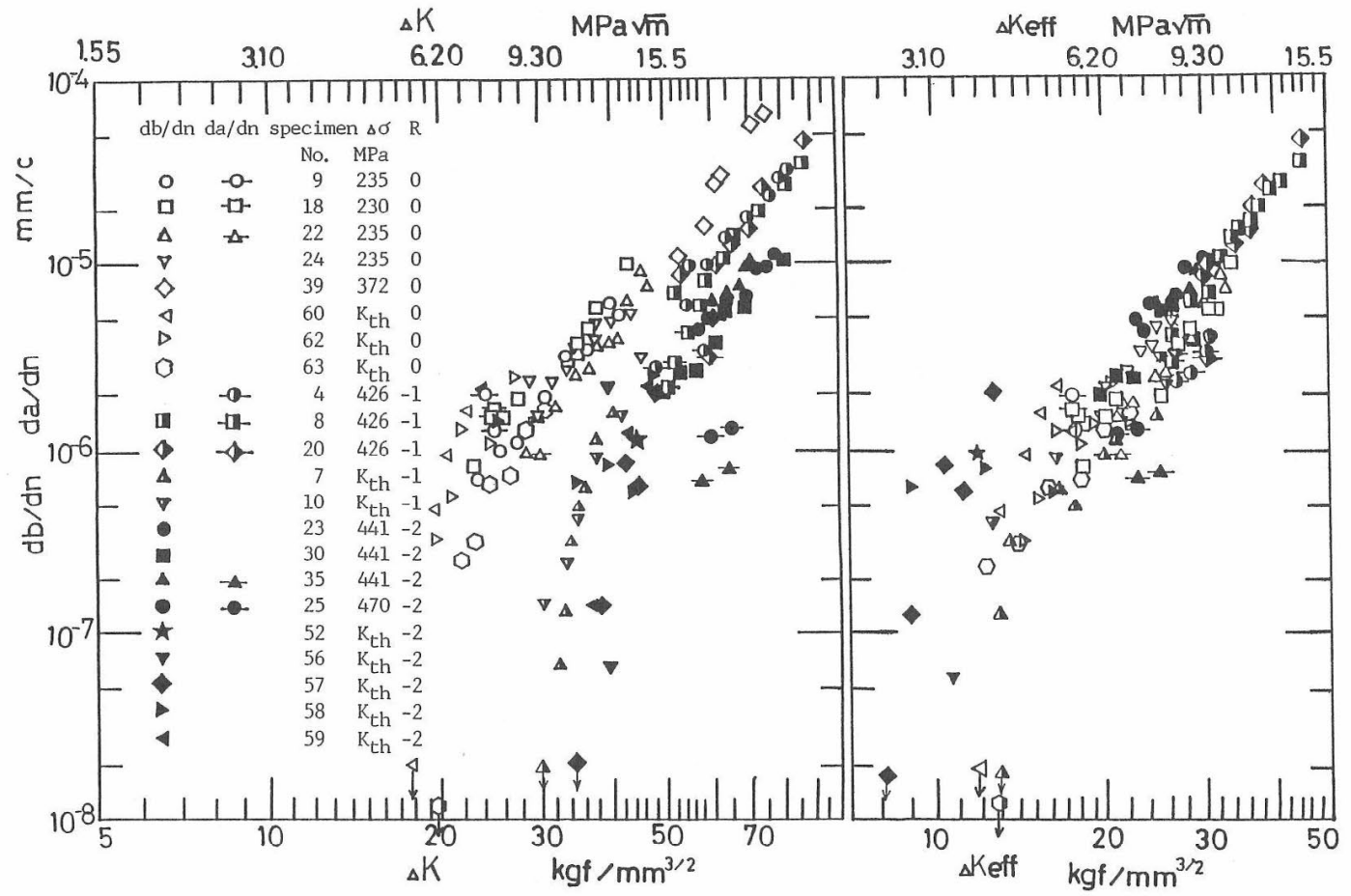

(a) $\Delta K$.

(b) $\Delta K_{\text {eff }}$.

Fig. 4. Crack propagation rates as a function of $\Delta K$ or $\Delta K_{\text {eff }}$.
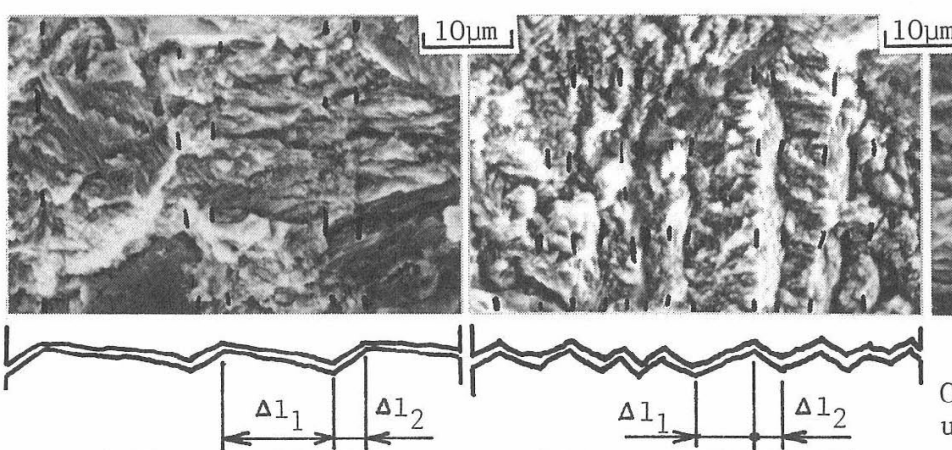

(a)Program I (No.72)

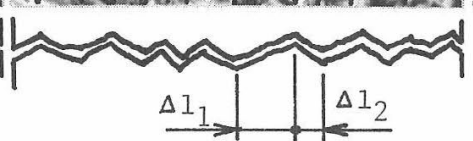

(b) Program II (No.108)

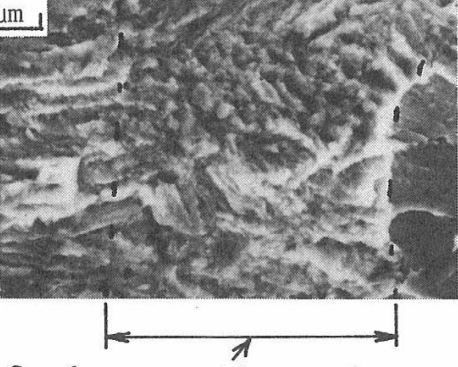

Crack propagation region under periodic overstressing (c) Program III (No.73)

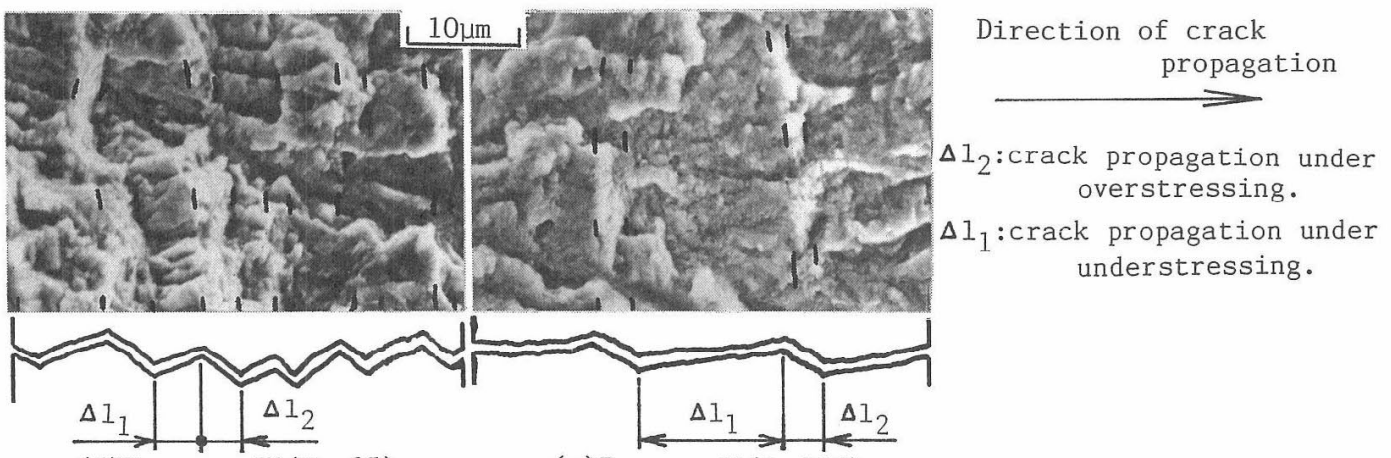

(d)Program N (No.65)

(e) Program V (No.106)

Fig. 5. Microfractographs of specimens tested under periodic overstressing. 
Table I. Crack propagation data under periodic overstressing.

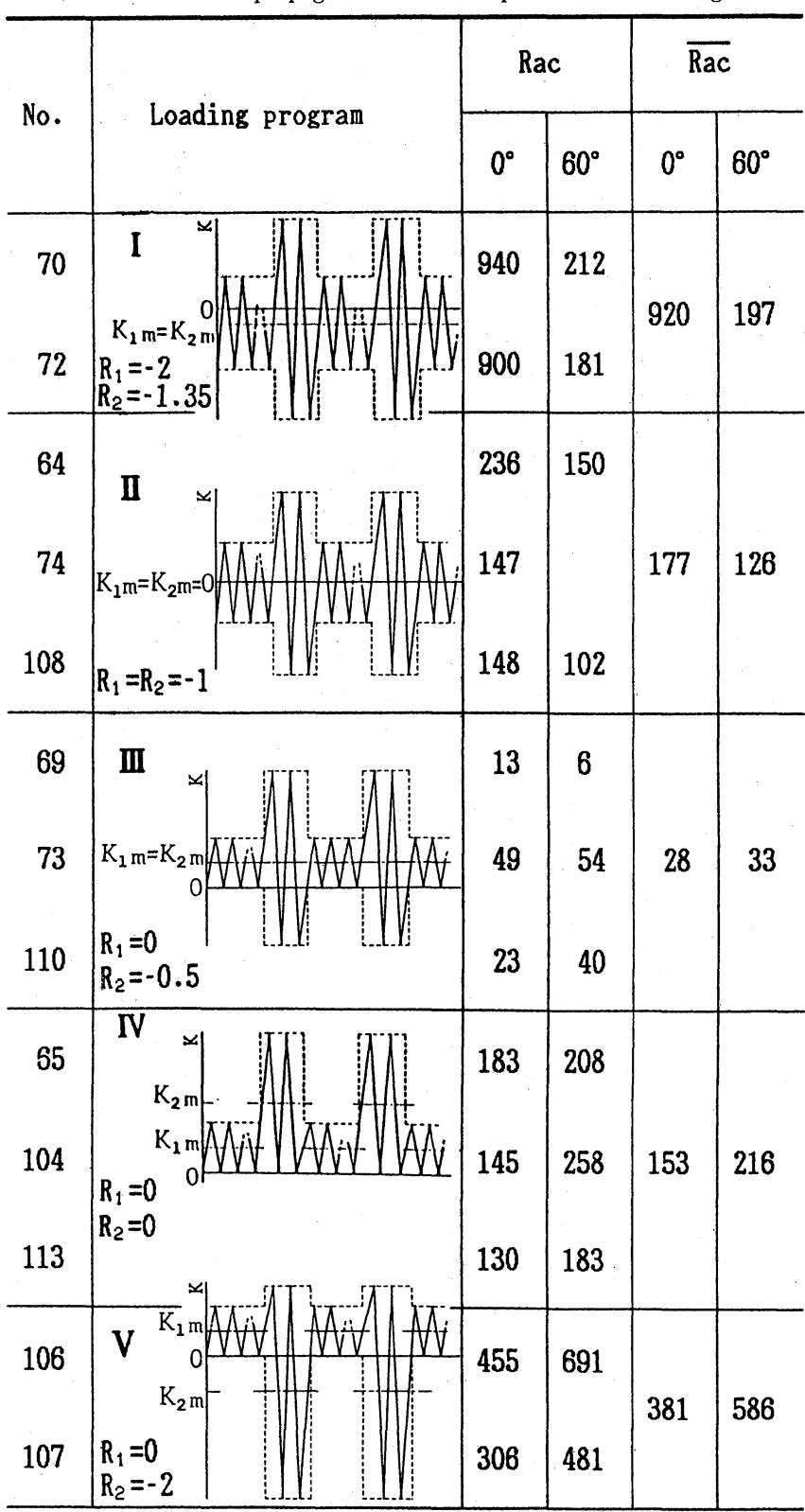

$\mathrm{K}_{1 \mathrm{~m}}$ : mean stress of understress

$\mathrm{K}_{2 \mathrm{~m}}$ : mean stress of overstress

$\mathrm{R}_{1}$ : stress ratio of understress

$\mathrm{R}_{2}$ : stress ratio of overstress

つぎに過小応力はすべて片振りで過大の平均応力 $K_{2 \mathrm{~m}}$ のみを变えた負荷プログラム III， $\mathrm{I} ， \mathrm{~V}$ を見ると， この場合も上記と同様， $K_{2 \mathrm{~m}}$ が圧縮のプログラム $\mathrm{V}$ が 最も大きい加速を示した。 ただし，次は中間の $K_{2 \mathrm{~m}}$ のIII（引張りの平均応力を有する両振り）ではなく, 大きい引張りの $K_{2 \mathrm{~m}}$ の $\mathrm{N}$ （片振り）となった．表面 と内部を比べると，上記とは逆に内部の加速の方が大 きい.
過大過小応力下のき裂伝ぱ部の破面写 真例を，立体マッチング観察して描いた 断面模型図とともに Fig. 5 に示す．加速 の小さい囵を除いたすべての負荷プログ ラムにおいて，過大および過小応力に対 応するしま模様が現れている，過大応力 部分は高伝ぱ速度域のストライエーショ ン間に見られるすべり線状模様，過小応 力部分は低伝ぱ速度域の破面の特徵であ るき裂伝ぱ方向に平行な幅の狭いプラト 一とその上のストライエーション状模様 からなっている．き裂進展機構は断面模 型図に見られるように山と谷, 谷と山が 対応するジグザグ進展を示した．以上は 筆者の一人らが巨視貫通き裂の高加速域 で観察している結果亡同様であり，表面 き裂においても, 過大過小応力下の顕著 な加速現象は, 過小応力の多数回の繰返 しによる組織回復と過大応力負荷により き裂先端部に生じた放射状組織に沿うき 裂のジグザグ進展が関係しているものと 考えられる. 過小応力はいずれも片振り で, 過大応力の平均応力を引張りとした プログラム III と，さらに大きい片振り引 張りとした同IVについて，上記のように IIIではなく IVが大きな加速を生じ, ジグ ザグ進展を示した。この原因は明らかて ないが, 過大の平均応力が引張りの大き な值になると過大応力の最大応力も大き くなり，これに伴ってき裂先端での塑性 変形が大きくなり゙, その結果, き裂先端 近傍の局所的な塑性変形に関係するとみ られる上述した放射状組織が形成された ためではないかと考えられる。この放射 状組織は転位密度が高く比較的不安定と みられ，引続き繰返し負荷される過小応 力下ではこの放射状組織に沿う組織回復 と, 回復に関連したき裂進展が生じ，さ らにこの回復が次の過大応力下のき裂進 展の加速と放射状組織の形成を促進して ジグザグ進展を示し，大きな加速を生じたものと推測 される。

\section{4 結言}

$\mathrm{S} 20 \mathrm{C}$ 焼ならし材を用いて, 定常および過大過小応 力下の表面疲労き裂伝ぱ試験を種々の平均応力を用い

*3一回目の過大応力の最大応力負荷時のき裂先端の塑性変形と関連 する CTOD は, 繰返し有効過小応力による CTOD と過小応力の 最大応力以上過大応力の最大值までの一方向負荷による CTOD を加えた值 ${ }^{11)}$ となり，IVの方が吕よりも約 1.5 倍大きい 
た曲げ応力下で行い，き裂伝ぱ挙動に及ぼす平均応力 の影響について検討した. 得られた結果は以下の通り である。

\section{$4 \cdot 1$ 定常応力下のき裂伝ぱ試験}

(1) き裂前縁形状は平均応力が引張り $(R=0)$ か らゼロ $(R=-1)$, 圧縮 $(R=-2)$ となるにつれて, 表面方向により長い半だ円形状を示した.

(2) $\Delta K$ に対する試験片表面方向と深さ方向の伝ぱ 速度の大きさは, 平均応力が引張り $(R=0)$ のとき ほほ等しく，ゼロ $(R=-1)$, 圧縮 $(R=-2)$ とな るにつれて深さ方向の伝ぱ速度がより小さくなり，き 裂前縁形状の結果と対応した. マクロ破面観察結果は, 平均応力の違いによるき裂伝ぱ速度のこの差異が酸化 物誘起き裂閉口に関係していることを示唆したが，ひ ずみゲージを用いたコンプライアンス法によるき裂開 閉口の測定では, 試験片表面のき裂先端前方と背面中 央のゲージ出力から得たき裂開ロレベルに明瞭な差異 は見られなかった。

\section{$4 \cdot 2$ 過大過小応力下のき裂伝ぱ試験}

（1）過大過小応力下のき裂伝ぱ速度は, 過大と過小 の平均応力が等しいとき, 平均応力が引張りから, ゼ ロ，圧縮となるにつれ大きい加速を生じた.

（2）過小応力はすべて片振りとし, 過大応力の平均 応力を高い引張り, 低い引張り, 圧縮と変えたときも, (1) と同様, 圧縮の平均応力で最も大きな加速を生じ た.しかし，次に加速が大きいのは中間の低い引張り の平均応力の場合ではなく, 高い引張りの平均応力 (片振り) の場合であった.
（3）加速が小さな場合を除いて，巨視貫通き裂の高 加速域で観察されたのと同様なジグザグ進展が観察さ れ, 表面き裂においても, 巨視貫通き裂と同様, 過小 応力の多数回の繰返しによる組織回復と過大応力負荷 による放射状組織に沿うジグザグ進展機構が顕著な加 速現象と関係しているものと考えられる.

(平成 2 年 6 月 22 日 第 7 回フラクトグラフィシンポジウムにて講演)

\section{参 考 文 献}

1 ) 例えば, 金沢 武, 町田 進, 系賀興右, 日本造船学会 論文集, No. 132, 395 (1972); 川原正言, 栗原正好, 日本造船学会論文集, No. 137, 297 (1975); J. B. Chang, ed., ASTM STP 687 (1979).

2 ) 小寺沢良一, 大橋喜法, 渡辺 寛, 材料, $\mathbf{2 7}, 363$ (1978).

3 ) 小寺沢良一, 材料, 27, 871 (1978).

4 ）小寺沢良一, 志茂大治郎，材料， 25，875 (1976).

5 ) 藤田和孝, 小寺沢良一, 材料, 34, 687 (1985).

6 ) J. C. Newman, Jr. and I. S. Raju, Eng. Fract. Mech., 15, 185 (1981).

7 ) ASTM Committee E-24, ASTM STP 738, 340 (1981).

8 ) 菊川 真, 城野政弘, 田中健一, 高谷 勝, 材料, 25, 899 (1976).

9 ) 平野一美, 小林英男, 中沢 一, 林 昭夫, 日本機械学 会論文集，A-52，2480（1986）.

10) K. Katagiri, R. Koterazawa, T. Yamada and T. Tsuboi, Metal Science, 17, 556 (1983).

11）小寺沢良一, 本上 勉, 材料, 23, 730 (1974). 